\title{
MESOPOROUS SILICA (MCM-41): SYNTHESIS/MODIFICATION, CHARACTERIZATION AND REMOVAL OF SELECTED ORGANIC MICRO-POLLUTANTS FROM WATER
}

Milica D. Branković*, Aleksandra R. Zarubica, Tatjana D. Andjelković, Darko H. Andjelković

(REVIEW PAPER)

UDC 66.018:628.3:504.5

Department of Chemistry, Faculty of Science and Mathematics, University of Niš, Niš, Serbia

In the removal of organic micro-pollutants from water, in addition to microporous there are mesoporous adsorbents that are increasingly gaining in importance. Mesoporous silica-based materials like MCM-41 have a high specific surface area and a large pore volume, properties that provide a high adsorption capacity towards pollutants. However, these materials have low hydrothermal stability which represents the main disadvantage in their wider usage in water treatments. Through the optimization of synthesis parameters and various post-synthetic modifications, better material characteristics may be achieved. Usually applied techniques for the material characterization are X-ray diffraction, $\mathrm{N}_{2}$-BET method, SEM, TEM and FTIR. The removal efficiency of water pollutants is determined by the MCM-41 structure, but also by the chemical structure of pollutants and in general depends on the $\mathrm{pH}$ and ionic strength of the treated water solutions.
Keywords: mesoporous materials, MCM41 , water treatment, pollutants

\section{Introduction}

Microporous adsorbents, like activated carbon or zeolites with high Si/Al ratio are commonly used for the removal of organic micro-pollutants from gaseous and water samples. Due to the presence of a number of narrow pores inside the total porous system, these materials may have a relatively low adsorption capacity for larger organic molecules, and internal diffusion restrictions may occur during the adsorption process. Frequent pore blocking with stereo-chemically large molecules of pollutants in exclusively microporous adsorbents contributes to difficult regeneration of these adsorbents. The potential internal and external diffusion restrictions, in microporous adsorbents applied in adsorption studies, give an advantage to mesoporous adsorbents. Mesoporous silica-based materials have both amorphous characteristics of gels and the ordered structure of crystalline materials. In the organic pollutants removal these materials have become more and more important, because they can be adjusted to target molecules with the help of the template synthesis method, may be economically regenerated and reused. The commonly used mesoporous silica-based materials are with small pores: hexagonal arranged MCM-41 (MCM-Mobil Composition of Matter) and cubic arranged MCM-48, and with large pores: hexagonal SBA-15 (SBA-Santa Barbara Amorphous) and cubic SBA-16 and a range of hexagonal mesoporous silica [1].

\section{Material nature}

Mesoporous silica is an adsorbent of good choice due to the arranged mesoporous structure with a uniform pore size $(2-50 \mathrm{~nm})$, which enables selective adsorption of small molecules. A high surface area $\left(\approx 1600 \mathrm{~m}^{2} / \mathrm{g}\right)$ and a large pore volume of mesoporous silica-based materials are responsible for their high adsorption capacity [2]. A limiting factor in wider application of these materials is low hydrothermal stability, which is reflected in typical pore shape loss/deformation and pore size reduction after a prolonged contact with alkaline aqueous solutions and at increasing temperatures [3]. The approach to increase hydrothermal stability is to control $\mathrm{pH}$ and ionic strength of the solution and to change the conditions and template-removing techniques during the synthesis procedure [4-6]. Thermal stability of MCM-41 can be improved remarkably by using low molar ratio of surfactant/ tetraethyl orthosilicate (TEOS) during the hydrothermal synthesis process [7]. The indicators of good hydrothermal stability are pores with the hexagonal shape in the range $50-80 \%$ of the total volume/structure, which was achieved by the synthesis carried out in different mother-liquids [8]. The use of aqueous and alkaline-aqueous solutions in the preparation procedure of silica-based materials resulted in highly-ordered MCM- 41 with the hexagonal pore shape and relatively low hydrothermal stability, whereas the application of an ammonia-alcoholic solution gave the ordered material with a pore shape between a hexagonal prism and cylinder and with high hydrothermal stability [8]. Post-synthetic modification, as a way of hydrothermal stability optimization, showed that the treatment of MCM-41 surface with TEOS did not result in higher wall thickness as expected, but in pore blocking. Moreover, coating with aggregated form of silica $\left(\mathrm{Na}_{2} \mathrm{SiO}_{3} \times 9 \mathrm{H}_{2} \mathrm{O}\right)$ gave better results, i.e. defective areas reconstruction and higher hydrothermal stability of MCM-41 [8]. Higher wall thickness can be also achieved by silylation and phenylation of MCM-41 silanol groups [9].

\footnotetext{
* Author address: Milica Branković, Department of Chemistry, Faculty of Science and Mathematics, University of Niš, Višegradska 33, 18000 Niš, Serbia

E-mail: milica.chem@outlook.com

The manuscript received: March, 27, 2017.

Paper accepted: May, 23, 2017.
} 
Table 1. Review of MCM-41 preparation techniques and morphological features of the synthesized material

\begin{tabular}{|c|c|c|c|c|c|c|c|}
\hline $\begin{array}{l}\text { Surfactant/Silica } \\
\text { precursor }\end{array}$ & $\begin{array}{l}\text { Mother- } \\
\text { liquid }\end{array}$ & $\begin{array}{c}\text { The molar composition of } \\
\text { the gel }\end{array}$ & $\begin{array}{l}\text { Calcin } \\
\text { ation } \\
\text { conditi } \\
\text { ons }\end{array}$ & $\begin{array}{l}\text { Particle } \\
\text { size } \\
(\mathrm{nm}) / \mathrm{Sp} \\
\text { ecific } \\
\text { area } \\
\left(\mathrm{m}^{2} / \mathrm{g}\right)\end{array}$ & $\begin{array}{c}\text { Pore } \\
\text { diam } \\
\text { eter } \\
(\mathrm{nm}) / \\
\text { Wall } \\
\text { thickn } \\
\text { ess } \\
(\mathrm{nm})\end{array}$ & $\begin{array}{l}\text { Spe } \\
\text { cific } \\
\text { pore } \\
\text { volu } \\
\text { me } \\
\left(\mathrm{cm}^{3}\right. \\
/ \mathrm{g})\end{array}$ & $\begin{array}{l}\text { Refer } \\
\text { ence }\end{array}$ \\
\hline CTAB/TEOS & $\mathrm{H}_{2} \mathrm{O}+\mathrm{NaOH}$ & $\begin{array}{c}1.0 \text { IEOS:0.10 ClAB:0.30 } \\
\qquad \mathrm{NaOH}: 60 \mathrm{H}_{2} \mathrm{O}\end{array}$ & $\begin{array}{l}813 \mathrm{~K} \\
124 \mathrm{~h}\end{array}$ & $-/ 871$ & $\begin{array}{l}2.61 / \\
2.12\end{array}$ & 0.79 & [7] \\
\hline CTAB/TEOS & $\begin{array}{c}\mathrm{H}_{2} \mathrm{O}+\mathrm{NH}_{3}+ \\
\mathrm{C}_{2} \mathrm{H}_{5} \mathrm{OH}\end{array}$ & $\begin{array}{c}\text { 1TEOS:0.2CTAB: } 21 \mathrm{NH}_{3}: 50 \\
\qquad \mathrm{C}_{2} \mathrm{H}_{5} \mathrm{OH}: 475 \mathrm{H}_{2} \mathrm{O}\end{array}$ & $\begin{array}{l}823 \mathrm{~K} \\
16 \mathrm{~h}\end{array}$ & $-/ 978$ & 10.94 & - & [8] \\
\hline CTAB/TMOS & $\begin{array}{c}\mathrm{H}_{2} \mathrm{O}+\text { methy } \\
\text { lamine } \\
\text { (MA) }\end{array}$ & $\begin{array}{c}\text { 1TMOS:0. } \\
\text { 215CTAB:2MA: } 120 \mathrm{H}_{2} \mathrm{O}\end{array}$ & $\begin{array}{l}823 \mathrm{~K} \\
14 \mathrm{~h}\end{array}$ & $-/ 992$ & $\begin{array}{l}3.32 / \\
0.68\end{array}$ & $\begin{array}{c}0.79 \\
3\end{array}$ & [9] \\
\hline $\begin{array}{c}\text { CTAB/tetramethyl } \\
\text { ammonium } \\
\text { silicate }+ \\
\text { precipitated silica } \\
\text { (HiSil) } \\
\text { (Addition of } \mathrm{Al}_{2} \mathrm{O}_{3} \text { ) }\end{array}$ & - & - & $\begin{array}{l}813 \mathrm{~K} \\
/ 7 \mathrm{~h}\end{array}$ & $\mid \geq 1000$ & $3 /-$ & 0.79 & {$[10]^{*}$} \\
\hline $\begin{array}{c}\text { CTAT+Pluronic } \\
\text { F68/TEOS }\end{array}$ & $\mathrm{H}_{2} \mathrm{O}+\mathrm{NaOH}$ & $\begin{array}{c}\text { 1TEOS:0.53NaOH:0.011CT } \\
\text { AT: } 0.0037 \mathrm{~F} 68\end{array}$ & $\begin{array}{l}813 \mathrm{~K} \\
17 \mathrm{~h}\end{array}$ & $\begin{array}{c}1500 / 46 \\
8\end{array}$ & $\begin{array}{l}1.94 / \\
1.47\end{array}$ & $\begin{array}{c}0.47 \\
4\end{array}$ & [11] \\
\hline CTAB/TEOS & $\mathrm{H}_{2} \mathrm{O}+\mathrm{NH}_{3}$ & - & $\begin{array}{l}813 \mathrm{~K} \\
19 \mathrm{~h}\end{array}$ & $-/ 1460$ & $\begin{array}{c}2.1 / 1 \\
66\end{array}$ & $\begin{array}{c}0.65 \\
3\end{array}$ & [12] \\
\hline CTAB/TEOS & $\begin{array}{c}\mathrm{H}_{2} \mathrm{O}+\mathrm{NH}_{3}+ \\
\mathrm{C}_{2} \mathrm{H}_{5} \mathrm{OH}\end{array}$ & $\begin{array}{c}\text { 1TEOS:0.3CTAB: } 11 \mathrm{NH}_{3}: 14 \\
4 \mathrm{H}_{2} \mathrm{O}: 58 \mathrm{C}_{2} \mathrm{H}_{5} \mathrm{OH}\end{array}$ & $\begin{array}{l}823 \mathrm{~K} \\
/ 5 \mathrm{~h}\end{array}$ & $806.5 /-$ & - & - & [14] \\
\hline
\end{tabular}
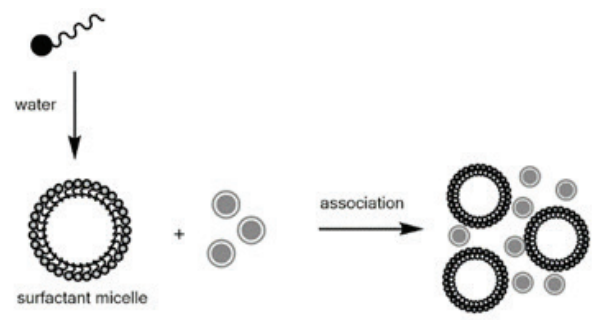

self-organization
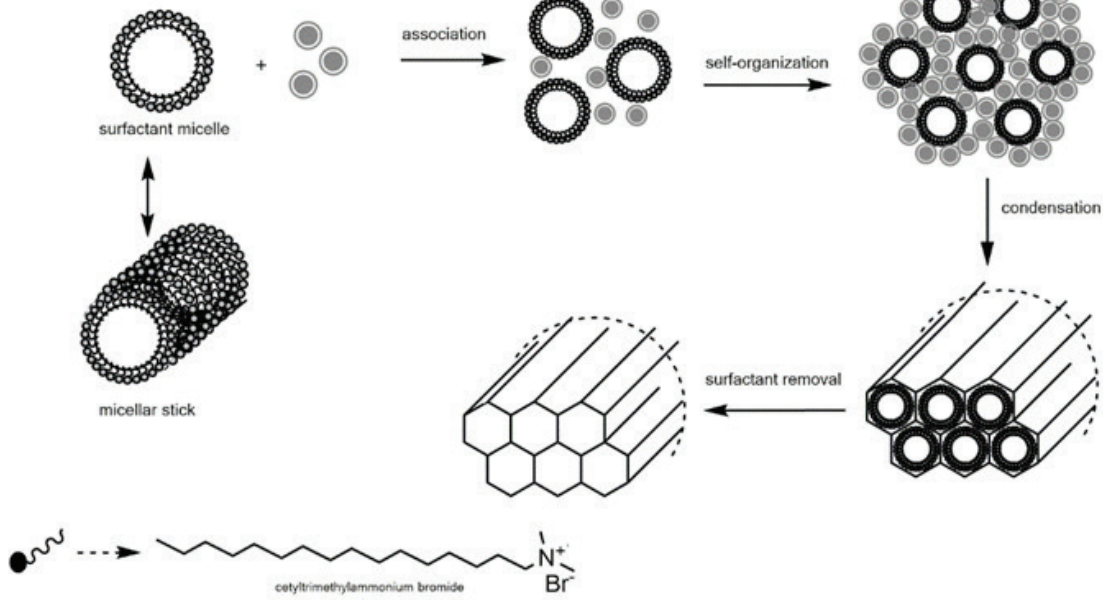

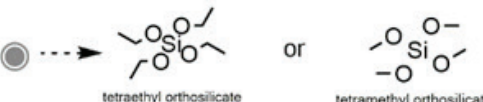

Figure 1. Schematic diagram of silica-based mesoporous materials synthesis 


\section{Material synthesis and characterization}

Material preparation

The original synthesis of MCM-41 includes hydrothermal transformation of basic silicate or aluminosilicate gels in the presence of quaternary ammonium surfactants with different alkyl chain lengths. According to the authors of original MCM-41 synthesis [10] mesoporous molecular sieves are formed by a "liquid-crystal templating" mechanism, where as they stated "inorganic material occupies the continuous solvent (water) region to create inorganic walls between the surfactant cylinders". In other words, the synthesis of silica-based mesoporous materials is based on the use of template around which arranged tunnels are formed, by covering silica precursors through the process of polycondensation (Figure 1). As compared to the original MCM-41 synthesis, besides cetyltrimethylammonium bromide (CTAB) as cationic surfactant from the class of quaternary ammonium, salts can be also used ammonium salts with other counter ions (CTAX; $\mathrm{CTA}^{+}$-cetyltrimethylammonium cation; $\mathrm{X}$ tosylate or chloride anion) or even surfactant mixture CTAX + amphiphilic copolymer Pluronic F68 are usually used [11], while as silica precursors alkoxides (TMOS - tetramethyl orthosilicate; TEOS - tetraethyl orthosilicate) or cheaper sodium-silicate [3]. The parameters of the preparation procedures and selected textural and/ or morphological characteristics of synthetized MCM-41 are given in Table 1.

The morphology of the final silica-based material depends on synthesis conditions, i.e. reaction time, $\mathrm{pH}$ of the mother-liquid, a surfactant type and concentration, the surfactant/silicon mole ratio [3, 8,10-13]. The longer reaction time, for example, makes the MCM-41 pore size decrease [12]. The use of ammonium surfactants with different chain length $(n=8,9,10,12,14,16)$ results in MCM-41 materials, each with different XRD spacings [13]. The carbon chain length of the surfactant determines the dimensions of formed micelles and thereby the dimensions of the MCM-41 pores i.e. the MCM-41 pore diameter increases with the surfactant chain length [13]. The development of the mesoporous structure of the synthesized material is achieved by surfactant removal through several processes, commonly by the process of the calcination/thermal treatment. However, in the aqueous solution calcined meso-silica has low binding affinity towards hydrophobic pollutants due to high silanol group density in meso-tunnels. Hydrophobicity of silica can be improved by silanol group functionalization, i.e. by the post-synthesis grafting process or the co-condensation process [3]. Silylation of MCM-41 with hexamethyldisilazane (HMDS) increases the carbon content in the silica matrix up to $8.5 \%$, whereas silanol density decreases from 2.31 to $0.87 \mathrm{OH} / \mathrm{nm}^{2}$, leading to the loss of water binding capacity in the case of higher silylated MCM-41 [9].

\section{Characterization}

The characterization of the synthesized material is achieved by using various techniques like transmission electron microscopy (TEM), scanning electron microscopy (SEM), X-ray diffraction (XRD) technique, N2-BET method and Fourier-transformation Infrared Spectroscopy (FTIR) $[8,9,11,14,15]$. TEM provides information about material morphology of/in higher resolution, whereas the importance of SEM is in determination in smaller resolution (Figure 2). Brigante and Avena [11] have synthetized MCM-41 by using the mixture of two surfactants, one of which (Pluronic F68) is used in SBA-16 synthesis [16,17], so there was a possibility to obtain a material with both hexagonal and/or cubic structure. The obtained wall thickness of $1.47 \mathrm{~nm}$ determined by SEM, which does fit the range of $0.8-2.5 \mathrm{~nm}$ for MCM-41 material, confirmed that the synthesized material was MCM- 41 .

$\mathrm{XRD}$ technique allows the secondary electron density maps calculation which then can be used to track the changes in hydrothermal properties - in the crystal structure of MCM-41 caused by different synthesis conditions [8] and the determination of the structure arrangement of MCM-41 after post-synthetic modifications [9]. XRD pattern containing three peaks with decreasing intensity, indexed as (100), (110) and (200) (Figure 3) is typical for a material with hexagonal lattice arrangement [18] and it is a proof that the synthesized material is MCM-41. The decrease in the intensity of peaks at Bragg angles bigger than the same ones of the first peak indicates a lower so-called "long-range"/3D ordering of the pore structure $[9,19]$ and the inversion of the intensity of these peaks indicates the occurrence of new micro-pores in the structure [8].

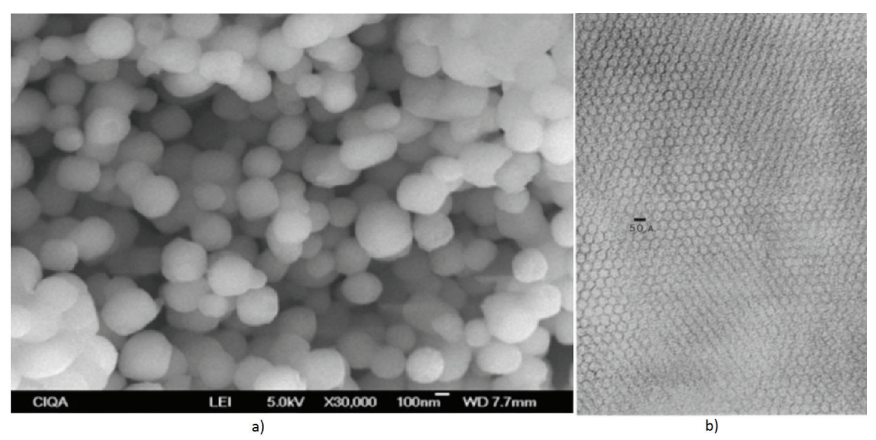

Figure 2. a) Scanning electron micrograph [12]; b) transmission electron micrograph [10] of MCM-41 material

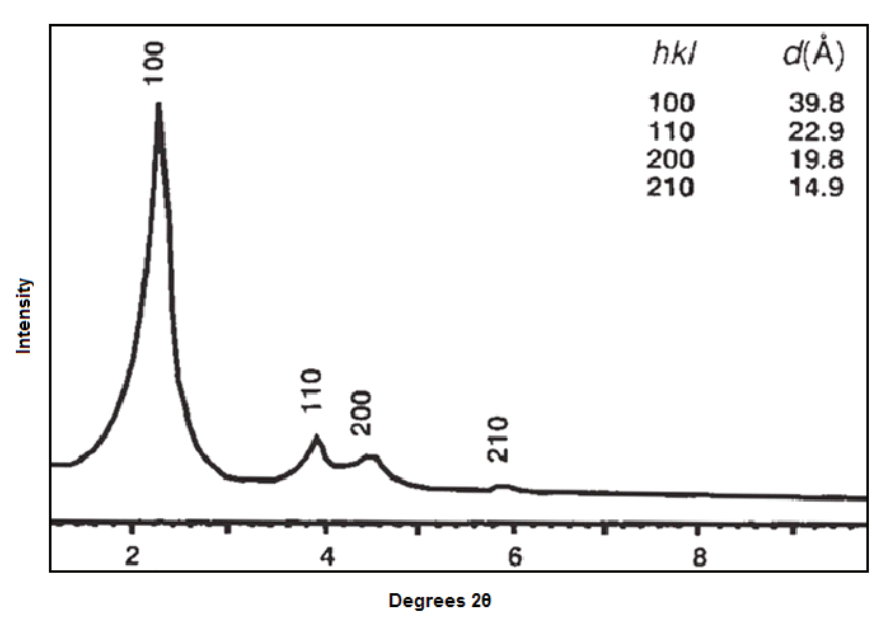

Figure 3. XRD pattern of MCM-41 [10]

The process of capillary condensation of gases is typical for porous materials and is used for the specific surface area and pore size (range) determination, by studying sorption isotherms [20,21]. Commonly stud- 
ied isotherms are nitrogen isotherms (figure 4) which for mesoporous silica materials belong to the type IV of sorption isotherms, with a sharp increase of the adsorbed nitrogen volume at the medium relative pressure (P/Po) $[9,11]$. The relative pressure at which the condensation begins depends on a pore diameter, i.e. these two values are inversely proportional [22]. Thus, for calcined MCM-41, with the pore size of $3.32 \mathrm{~nm}$, nitrogen condensation occurs at $\mathrm{P} / \mathrm{Po}=0.06$, whereas for phenylated and silylated MCM-41, with the pore size range of 2.78$2.91 \mathrm{~nm}$, at higher relative pressures of 0.16 [9]. Uniformity of the pore size affects the condensation, where with the less pore uniformity, the less sharp is the pore condensation step [22]. Moreover, the uniformity of the pore diameters influences the occurrence or the absence of hysteresis loop in sorption isotherms. Hysteresis loop is not common for MCM-41 with the uniform pore size [9], whereas for plate-like particles, i.e. slit-shaped pores hysteresis loop of type $\mathrm{H} 3$ is manifested $[11,22]$.

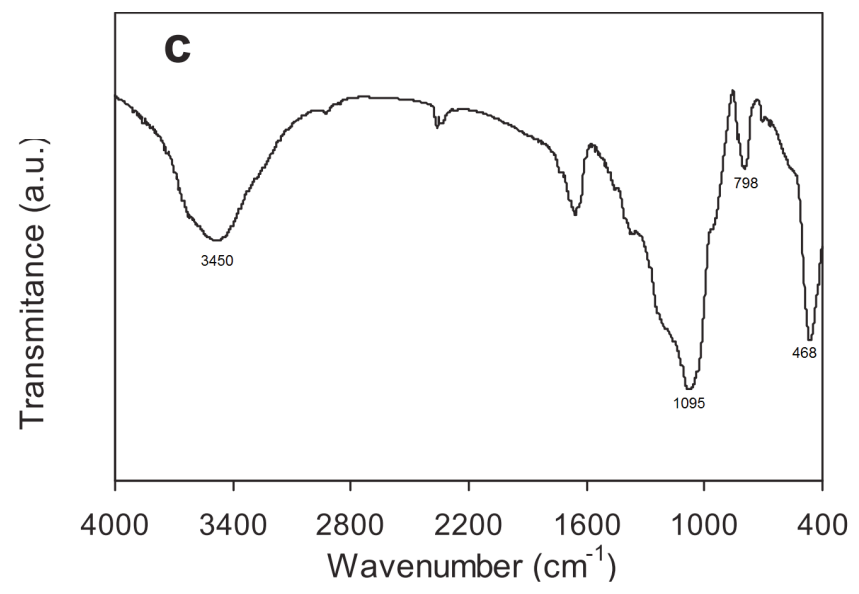

Figure 4. N2 adsorption-desorption isotherms of MCM-41 [10]

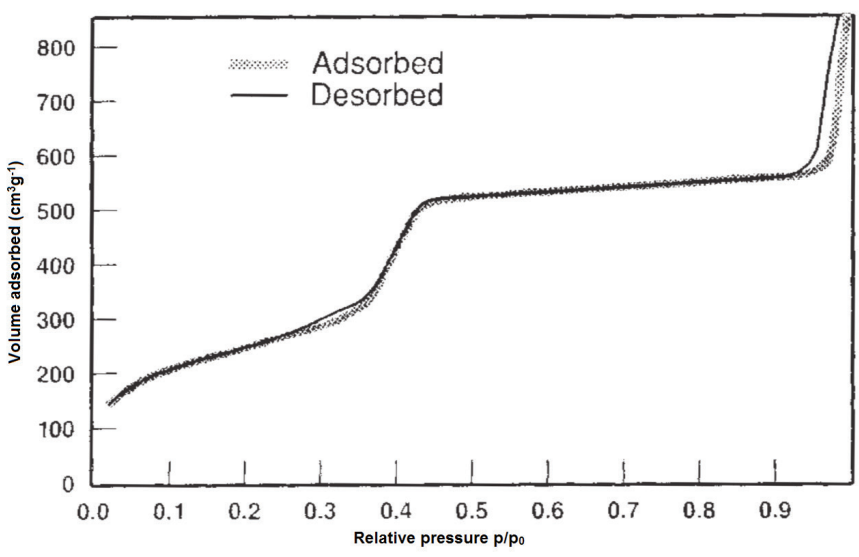

Figure 5. FT-IR spectra of mesoporous silica [11]

FTIR characterization of MCM-41 (Figure 5) shows several absorption maximums: at $3504 \mathrm{~cm}^{-1}$ - a broad band related to $\mathrm{OH}$ stretching of silanol groups; at 1654 $\mathrm{cm}^{-1}$ - a peak related to $\mathrm{OH}$ bending from water molecules; at $1078 \mathrm{~cm}^{-1}$ - a peak related to asymmetric Si-
O-Si vibrations and at $795 \mathrm{~cm}^{-1}$ related to symmetric SiO-Si vibrations; at 962 and $465 \mathrm{~cm}^{-1}$ - peaks associated with Si-O-Si bending [23].

\section{Removal of selected organic micro-pollutants from} water samples

Influence of modification of adsorbents

There are several factors affecting MCM- 41 removing efficiency of organic micro-pollutants. As mentioned before, calcined MCM-41 has low affinity towards water pollutants, so many modifications are carried out in order to improve adsorbent hydrophobicity and thereby affinity. In tetracycline removal from water, MCM-41 impregnated with zeolite $A$ is much more efficient than non-modified MCM-41 [15]. The adsorption capacity of acetylsalicylic acid over hydrothermally synthesized iron oxide-mesoporous silica MCM-41 composites was much higher than over non-modified MCM-41, i.e. the adsorption capacity increases from 0.052 for the non-modified adsorbent to $6.189 \mathrm{mg} / \mathrm{g}$ for the adsorbent with 12.37 $\mathrm{Fe} / \mathrm{Si}$ molar ratio [24]. Also, after functionalization of MCM-41, DEET (N, N-diethyl-m-toluamide) the adsorption increases from 8.2 to $175.4 \mathrm{mg} / \mathrm{g}$ for highly silylated MCM-41 [9].

Adsorption and kinetic studies

In adsorption studies, isotherm models are used to measure the adsorption capacity of the adsorbent, equilibrium constant and the adsorbate distribution between the liquid phase and the solid phase. The Langmuir isotherm model is used to describe homogeneous, while the Freundlich isotherm model is applicable to heterogeneous adsorption systems. In most cases, the adsorption of pollutants over modified or non-modified MCM-41 is better described with the Langmuir isotherm model, which suggests that the MCM- 41 as adsorbent is homogeneous and the adsorption layer over its surface is monomolecu$\operatorname{lar}[25-27]$.

The pseudo-first order and pseudo-second-order equations are usually used to describe the adsorption mechanism of the solid adsorbent in the solution. The adsorption process of pollutants on MCM-41 is in accordance with pseudo-second-order kinetics $[25,26,28]$ and in general, pollutants are adsorbed relatively quickly (Figure 6).

For example, the time required to reach the adsorption equilibrium for the nitrobenzene-MCM-41 system [27] and the nitrobenzene-surface silylated MCM-41 system [29] is achieved within $1 \mathrm{~min}$. The kinetics of the adsorption of the mixture of polycyclic aromatic hydrocarbons by Si-MCM-41 was slightly slower, achieving equilibrium in approximately $60 \mathrm{~min}$ with $90.40,90.84$, and $92.98 \%$ removal of benzo[k]fluoranthene, benzo[b] fluoranthene, and benzo[a]pyrene, respectively [26]. After the same time, equilibrium was reached for the system phenanthrene-template-containing MCM-41 [28]. 

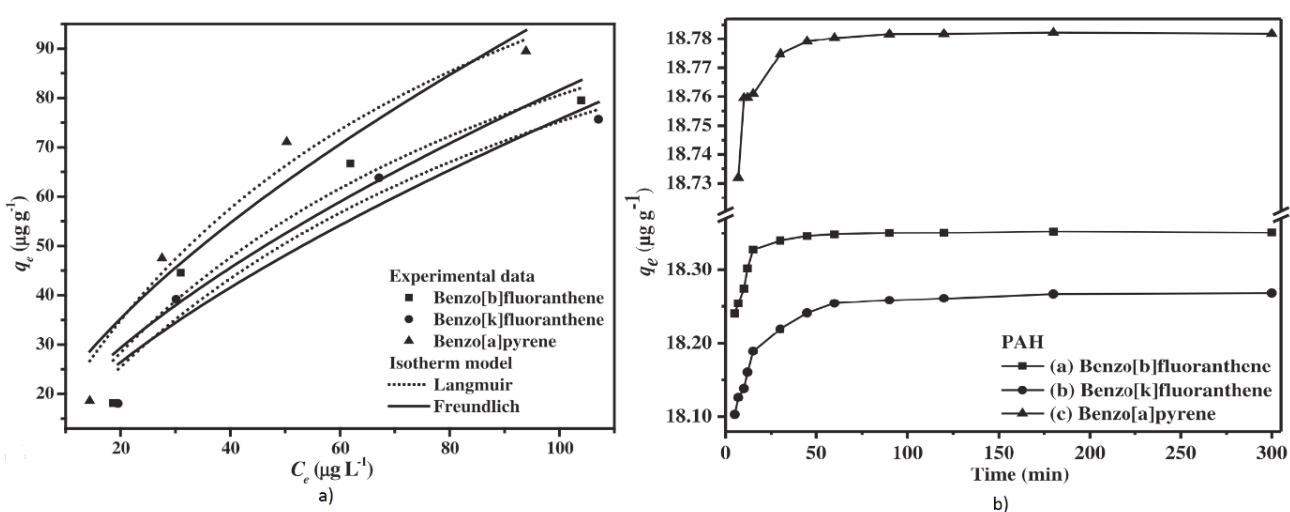

Figure 6. Adsorption kinetics for the mixed PAHs - Si-MCM-41 system [26]; a) Freundlich and Langmuir isotherm models; b) effect of contact time

Influence of adsorbent dose

The adsorbent dose positively affects the pollutant removal percentage, e.g. the removal percentage of phenanthrene increased up to $94 \%$ with the increase in template-containing MCM-41 dose up to $0.4 \mathrm{~g} / \mathrm{L}$, mainly due to the increase in number of active adsorption sites [28]. Furthermore, methyl blue adsorption capacity increased with the amount of Ni-MCM-41 and reached its maximum at $20 \mathrm{mg}$ of the adsorbent [30]. However, the percentage removal of phenol and o-chlorophenol increased with the increase in MCM-41 dose while loading capacity (the amount of phenol/o-chlorophenol loaded per unit weight of adsorbent) decreased [31].

\section{Influence of initial $\mathrm{pH}$}

Adsorption of pollutant on MCM-41 is $\mathrm{pH}$ dependent $[11,14,15,32]$, because of the nature of adsorbent-surface interaction. For example, the adsorption capacity of o-chlorophenol and phenol is constant at $11>\mathrm{pH}>7$ and $9>\mathrm{pH}>7$, respectively, where at acidic $\mathrm{pH}$ the adsorption capacity of both of them decreases due to the interaction of protons with silanol groups of MCM-41 via hydrogen bonding [31]. MCM-41 isoelectric point is at $\mathrm{pH}=2.63$, which means that above this $\mathrm{pH}$, the adsorbent surface has a negative charge due to the presence of -SiO- species, and bellow 2.63 the surface is positively charged due to $-\mathrm{SiOH}_{2+}$ species [3]. In which way $\mathrm{pH}$ affects the adsorption also depends on the pollutant structure. The adsorption of cationic pesticide paraquat from the aqueous solution, which binds to the adsorbent by electrostatic interactions and ion-pairs formation increases as $\mathrm{pH}$ increases, due to the creation of a larger number of negatively charged sites that can bind cationic pesticide [11]. On the other hand, bentazone adsorption on MCM-41 decreases as $\mathrm{pH}$ increases and becomes insignificant at a neutral $\mathrm{pH}$ [32]. The removal percentage of bentazone from lake and wastewaters by using adsorbent MCM-41 is 61 and $73 \%$, respectively [32].

Influence of adsorbent dose

The adsorbent dose positively affects the pollutant removal percentage, e.g. the removal percentage of phenanthrene increased up to $94 \%$ with the increase in template-containing MCM-41 dose up to $0.4 \mathrm{~g} / \mathrm{L}$, mainly due to the increase in number of active adsorption sites [28]. Furthermore, methyl blue adsorption capacity increased with the amount of Ni-MCM-41 and reached its maximum at $20 \mathrm{mg}$ of the adsorbent [30]. However, the percentage removal of phenol and o-chlorophenol increased with the increase in $\mathrm{MCM}-41$ dose while loading capacity (the amount of phenol/o-chlorophenol loaded per unit weight of adsorbent) decreased [31].

\section{Influence of initial $\mathrm{pH}$}

Adsorption of pollutant on MCM-41 is $\mathrm{pH}$ dependent $[11,14,15,32]$, because of the nature of adsorbent-surface interaction. For example, the adsorption capacity of o-chlorophenol and phenol is constant at $11>\mathrm{pH}>7$ and $9>\mathrm{pH}>7$, respectively, where at acidic $\mathrm{pH}$ the adsorption capacity of both of them decreases due to the interaction of protons with silanol groups of MCM-41 via hydrogen bonding [31]. MCM-41 isoelectric point is at $\mathrm{pH}=2.63$, which means that above this $\mathrm{pH}$, the adsorbent surface has a negative charge due to the presence of -SiO- species, and bellow 2.63 the surface is positively charged due to $-\mathrm{SiOH}_{2}$ species [3]. In which way $\mathrm{pH}$ affects the adsorption also depends on the pollutant structure. The adsorption of cationic pesticide paraquat from the aqueous solution, which binds to the adsorbent by electrostatic interactions and ion-pairs formation increases as $\mathrm{pH}$ increases, due to the creation of a larger number of negatively charged sites that can bind cationic pesticide [11]. On the other hand, bentazone adsorption on MCM-41 decreases as $\mathrm{pH}$ increases and becomes insignificant at a neutral $\mathrm{pH}$ [32]. The removal percentage of bentazone from lake and wastewaters by using adsorbent MCM-41 is 61 and $73 \%$, respectively [32].

\section{Influence of ionic strength}

Natural waters contain a certain percentage of salts which is the reason why the impact of the ionic strength of the solution must be taken into account. As the concentration of salts increases, the number of available charges of silica decreases due to the specific adsorption of the opposite charged ions. In other words, as the ionic strength increases, the adsorption of species with the same charge as the surface charge increases, whereas the adsorption 
of species with the charge opposite of the surface charge decreases $[11,33]$. Pre-concentration validation of drugs from water onto MCM-41, done by Dahane et al. [14] revealed that within the salts concentration range $10^{-4}-10^{-1}$ $M$, the best recovery of drugs (71-95\%) is obtained for the salt concentration of $1 \times 10^{-3} \mathrm{M}$.

Pollutants recovery and adsorbents regeneration

The nature of the interaction of the pollutant and adsorbent affects pollutant desorption, which is significant for the pollutant recovery and easiness of the adsorbent regeneration. For pesticides mentioned above, in case of bentazone, the regeneration of $47 \%$ is achieved with water as eluent and $70 \%$ with the methanol-NaOH mixture [32], whereas $30 \%$ of paraquat is removed with water and $75 \%$ with $0.2 \mathrm{M} \mathrm{HCl}$ [11].

\section{Conclusions}

Due to unique characteristics like the medium pore size, pore size uniformity and an ordered tunnel structure mesoporous silica-based materials have become significant in adsorption and treatment of various polluted matrixes/media, including water. One of the most common silica-based materials is MCM-41 which has an ordered hexagonal structure. The research being conducted on this material reveals various relatively controversial data. Synthesis conditions, i.e. $\mathrm{pH}$ of the motherliquid, the composition and the ratio of reactants and additives affect morphological characteristics of the final adsorbent. Also, the final adsorbent does not have ideally balanced properties when it is used in the removal of micro-pollutants from water. In order to improve adsorbent hydrophobicity and affinity towards pollutants, various post-synthetic modifications have been conducted. Those modifications have also been conducted in order to increase mesopore wall thickness, thereby increasing hydrothermal stability, which for MCM-41 has shown to be low. Hydrothermal stability does not correlate with highly ordered MCM-41 with a hexagonal pore shape, but with the material with a relatively usual degree of ordering, and with pore shapes somewhere between the hexagonal prism and cylinder.

The removal efficiency of organic pollutants from water over MCM-41 and chemically modified MCM-41, like drugs or pesticides, is satisfactory with careful procedure optimization. The factor that most affects the adsorption degree, due to the nature of MCM-41, is $\mathrm{pH}$. Depending on the $\mathrm{pH}$ and the pollutant nature, adsorbate-adsorbent interactions are both hydrogen bonding and/or electrostatic interactions. When these last mentioned are the main interacting route, the adsorption capacity of pollutants becomes additionally dependent on the ionic strength of the solution. This factor must certainly be taken into account, because salts are natural components of water.

List of abbreviations

BET - Brunauer, Emmett and Teller
CTAB - Cetyltrimethylammonium bromide

DEET - N, N-diethyl-m-toluamide

FTIR - Fourier-transformation Infrared Spectroscopy

HMDS - Hexamethyldisilazane

MCM - Mobil Composition of Matter

SBA - Santa Barbara Amorphous

SEM - Scanning electron microscopy

TEM - Transmission electron microscopy

TEOS - Tetraethyl orthosilicate

TMOS - Tetramethyl orthosilicate

XRD - X-ray diffraction

\section{References}

[1] A. Walcarius, L. Mercier, Mesoporous organosilica adsorbents: nanoengineered materials for removal of organic and inorganic pollutants, Journal of Materials Chemistry, 20 (2010) 4487-4511.

[2] L. Zhao, H. Qin, R. Wu, H. Zou, Recent advances of mesoporous materials in sample preparation, Journal of Chromatography A, 1228 (2012) 193-204.

[3] L.T. Gibson, Mesosilica materials and organic pollutant adsorption: part B removal from aqueous solution, Chemical Society reviews, 43 (2014) 5173-5182.

[4] M. Luechinger, L. Frunz, G.D. Pirngruber, R. Prins, A mechanistic explanation of the formation of high quality MCM-41 with high hydrothermal stability, Microporous and Mesoporous Materials, 64 (2003) 203-211.

[5] Q.-H. Xia, K. Hidajat, S. Kawi, Improvement of the hydrothermal stability of fluorinated MCM-41 material, Materials Letters, 42 (2000) 102-107.

[6] Q. Li, Zh. Wu, D. Feng, B. Tu, D. Zhao, Hydrothermal Stability of Mesostructured Cellular Silica Foams, Journal of physical chemistry C, 114 (2010) 5012-5019.

[7] H. Chen, Y. Wang, Preparation of MCM-41 with high thermal stability and complementary textural porosity, Ceramics International, 28 (2002) 541-547.

[8] S.D. Kirik, V.A. Parfenov, S.M. Zharkov, Monitoring MCM-41 synthesis by X-ray mesostructure analysis, Microporous and Mesoporous Materials, 195 (2014) 21-30.

[9] A. Trouve, I. Batonneau-Gener, S. Valange, M. Bonne, S. Mignard, Tuning the hydrophobicity of mesoporous silica materials for the adsorption of organic pollutant in aqueous solution, Journal of hazardous materials, 201202 (2012) 107-114.

[10] J.S. Beck, J.C. Vartuli, W.J. Roth, M.E. Leonowicz, C.T. Kresge. Ordered mesoporous molecular sieves synthesized by a liquid-crystal template mechanism, Letters to nature, 359 (1992) 710-712.

[11] M. Brigante, M. Avena, Synthesis, characterization and application of a hexagonal mesoporous silica for pesticide removal from aqueous solution, Microporous and Mesoporous Materials, 191 (2014) 1-9.

[12] H.I. Meléndez-Ortiz, L.A. García-Cerda, Y. OlivaresMaldonado, G. Castruita, J.A. Mercado-Silva, Y.A. Perera-Mercado, Preparation of spherical MCM-41 molecular sieve at room temperature: Influence of the synthesis conditions in the structural properties, Ceramics International, 38 (8) (2012) 6353-6358.

[13] J.S. Beck, J.C. Vartuli, W.J. Roth, M.E. Leonowicz, C.T. Kresge, K.D. Schmitt, C.T.-W. Chu, D.H. Olson, E.W. Sheppard, S.B. McCullen, J.B. Higgins, J.L. Schlenker, A New Family of Mesoporous Molecular Sieves Prepared 
with Liquid Crystal Templates, Journal of the American Chemical Society, 114 (27) (1992) 10834-10843.

[14] S. Dahane, M. Martinez Galera, M.E. Marchionni, M.M. Socias Viciana, A. Derdour, M.D. Gil Garcia, Mesoporous silica based MCM-41 as solid-phase extraction sorbent combined with micro-liquid chromatography-quadrupolemass spectrometry for the analysis of pharmaceuticals in waters, Talanta, 152 (2016) 378-391.

[15] M. Liu, L.A. Hou, S. Yu, B. Xi, Y. Zhao, X. Xia, MCM41 impregnated with A zeolite precursor: Synthesis, characterization and tetracycline antibiotics removal from aqueous solution, Chemical engineering journal, 223 (2013) 678-687.

[16] G.S. Park, C.W. Ahn, M.W. Kim, Crystal Morphology of Mesoporous Silica Thin Films Synthesized by the Spin-Coating Method Using PEO-PPO-PEO Triblock Copolymer, Journal of the American Ceramic Society, 85 (2002) 2542-2544.

[17] M. Mesa, L. Sierra, J.L. Guth, Contribution to the study of the formation mechanism of mesoporous SBA-15 and SBA-16 type silica particles in aqueous acid solutions, Microporous Mesoporous Materials 112 (2008) 338- 350.

[18] Z.A. AlOthman, A.W. Apblett, Synthesis and characterization of a hexagonal mesoporous silica with enhanced thermal and hydrothermal stabilities, Applied Surface Science, 256 (2010) 3573-3580.

[19] D. Kumar, K. Schumacher, C. du Fresne von Hohenesche, M. Grün, K.K. Unger, MCM-41, MCM-48 and related mesoporous adsorbents: their synthesis and characterisation, Colloids and Surfaces A: Physicochemical and Engineering Aspects, 187-188 (2001) 109-116.

[20] F.Casanova, C.E. Chiang, Chang-Peng Li, I.V. Roshchin, A.M. Ruminski, M.J. Sailor, I.K. Schuller, Gas adsorption and capillary condensation in nanoporous alumina films, Nanotechnology, 19 (2008) (315709).

[21] K. Morishige, N. Tateishi, Accurate Relations between Pore Size and the Pressure of Capillary Condensation and the Evaporation of Nitrogen in Cylindrical Pores, Langmuir, 22 (2006) 4165-4169.

[22] A.Trunschke, Surface area and pore size determination, Modern Methods in Heterogeneous Catalysis Research, (2013) (http://docplayer.net/6959104-Surface-area-andpore-size-determination.html)

[23] K. Gude, V.M. Gun'ko, J.P. Blitz, Adsorption and photocatalytic decomposition of methylene blue on surface modified silica and silica-titania, Colloids and Surfaces A: Physicochemical and Engineering Aspects 325 (2008) 17-20.

[24] H.T. Teo, W.R. Siah, L. Yuliati, Enhanced adsorption of acetylsalicylic acid over hydrothermally synthesized iron oxide-mesoporous silica MCM-41 composites, Journal of the Taiwan Institute of Chemical Engineers, 65 (2016) 591-598.

[25] L.C. Juang, C.C. Wang, C.K. Lee, Adsorption of basic dyes onto MCM-41, Chemosphere, 64 (11) (2006) 19201928.

[26] J.A.S. Costa, R.A. de Jesus, C.M.P. da Silva, L.P.C. Romão, Efficient adsorption of a mixture of polycyclic aromatic hydrocarbons (PAHs) by Si-MCM-41 mesoporous molecular sieve, Powder Technology, 308 (2017) 434-441.

[27] Q. Qin, J. Ma, K. Liu, Adsorption of nitrobenzene from aqueous solution by MCM-41, Journal of colloid and interface science, 315 (1) (2007) 80-86.
[28] Y. Hu, Y. He, X. Wang, C. Wei, Efficient adsorption of phenanthrene by simply synthesized hydrophobic MCM41 molecular sieves, Applied Surface Science, 311 (2014) 825-830.

[29] Q. Qin, Y. Xu, Enhanced nitrobenzene adsorption in aqueous solution by surface silylated MCM-41, Microporous and Mesoporous Materials, 232 (2016) 143150.

[30] Y. Shu, Y. Shao, X. Wei, X. Wang, Q. Sun, Q. Zhang, L. Li, Synthesis and characterization of Ni-MCM-41 for methyl blue adsorption, Microporous and Mesoporous Materials, 214 (2015) 88-94.

[31] P.A. Mangrulkar, S.P. Kamble, J. Meshram, S.S. Rayalu, Adsorption of phenol and o-chlorophenol by mesoporous MCM-41, Journal of hazardous materials, 160 (2-3) (2008) 414-421.

[32] M.C. Bruzzoniti, R.M. De Carlo, L. Rivoira, M. Del Bubba, M. Pavani, M. Riatti, B. Onida, Adsorption of bentazone herbicide onto mesoporous silica: application to environmental water purification, Environmental science and pollution research international, 23 (2016) 5399-5409.

[33] W. Liu, J. Liu, X. Yang, K. Wang, Q. Wang, M. Yang, L. Li, J. Xu, pH and ion strength modulated ionic species loading in mesoporous silica nanoparticles, Nanotechnology 24 (41) (2013) 1-8. 
Izvod

\section{MEZOPOROZNI SILIKATNI MATERIJALI (MCM-41): SINTEZA, KARAKTERIZACIJA I PRIMENA U UKLANJANJU ODABRANIH ORGANSKIH ZAGAĐIVAČA IZ VODA}

Milica D. Branković, Aleksandra R. Zarubica, Tatjana D. Anđelković, Darko H. Anđelković

Pored mikroporoznih materijala koji se uglavnom koriste za uklanjanje organskih polutanata iz vode, mezoporozni materijali sve više dobijaju na značaju. Mezoporozni silikatni materijali kao što je MCM-41 imaju veliku specifičnu površinu i veliku zapreminu pora, osobine koje omogućavaju visok adsorpcioni kapacitet polutanata. Ovi materijali imaju i nedostatke, kao što je niska hidrotermalna stabilnost, koja predstavlja glavni problem šire primene u prečišćavanju voda. Bolje osobine materijala se mogu postići kroz optimizaciju parametara sinteze i različite postsintetske modifikacije. Instrumentalne tehnike koje se koriste u njihovoj karakterizaciji su XRD tehnika, $\mathrm{N}_{2}$-BET metoda, SEM, TEM i FTIR. Efikasnost uklanjanja polutanata iz vode je uslovljena strukturom MCM-41, ali i hemijskim sastavom i strukturom samog polutanta i u velikoj meri zavisi od pH i jonske jačine vodenog rastvora.
Ključne reči: mezoporozni materijali, MCM-41, prečišćavanje voda, polutanti 